\title{
BIOMARKER SEBAGAI INDIKATOR PARAMETER BATUAN SUMBER DAN LINGKUNGAN PENGENDAPAN BATUAN SUMBER MINYAK BUMI LAPANGAN TARAKAN KALIMANTAN TIMUR - INDONESIA
}

Ine Mustikasari

Jurusan Kimia, Fakultas Matematika dan Ilmu Pengetahuan Alam,Universitas Negeri Jakarta, Rawamangun 13220 , Jakarta

Corresponding author: inemustikasari@yahoo.co.id

\begin{abstract}
Abstrak
Penelitian dengan pendekatan geokimia molekul untuk memahami batuan sumber dan lingkungan pengendapan minyak bumi lapangan Tarakan. Tujuh ( 7 ) sampel telah dianalisis dengan metoda GC, GC - MS dan IR - MS. Kisaran rasio 20R Sterana $\mathrm{C}_{29} / \mathrm{C}_{27}$ antara 2,4 sampai 7,3 $>1$ menunjukkan ketujuh batuan sumber berasal dari daratan, nilai Canonial value (Cv) empat sampel $>0,47$ mengindikasikan batuan sumber berasal dari daratan, grafik antara Pristana/Phytana $(\mathrm{Pr} / \mathrm{Ph})$ terhadap $\mathrm{Cv}$ lima sampel mengindikasikan batuan sumber berasal dari daratan. Nilai rasio Pristana terhadap Phytana $(\mathrm{Pr} / \mathrm{Ph})$ berkisar antara 2,32 sampai 6,91 menjelaskan enam sampel berasal dari lingkungan pengendapan batuan sumber oksidatif sedangkan satu sampel berasal dari lingkungan pengendapan batuan sumber reduktif.
\end{abstract}

Kata kunci ; biomarker, geokimia, Sterana, Canonial value, Pristana/Phytana

\section{Pendahuluan}

Senyawaan biomarker adalah senyawa organik dengan struktur kimia yang mencerminkan struktur kimia asalan biologinya dari suatu sumber tertentu. Artinya senyawa prekusor turunan dari organisme hidup hanya mengalami perubahan minor selama proses diagenesis berlangsung karena rangka karbonnya tetap. Tabel 1 merupakan ringkasan dari beberapa sumber biologi yang berkaitan dengan batuan sumber dan lingkungan pengendapan batuan sumber untuk beberapa biomarker yang umum.

Pendekatan geokimia molekul dalam geokimia reservoar digunakan bukan hanya untuk eksplorasi lanjutan, melainkan dapat membantu meningkatkan dan mengembangkan produksi. Banyak bukti yang menunjukkan pendekatan geokimia molekul merupakan solusi problem-problem reservoar seperti kontinuitas fluida (Roos dan Ames, 1988), alokasi produksi (Kaufman dkk, 1990), sejarah pengisian reservoar dan pencampuran (England, 1990). Kesemua ini menunjukkan metoda geokimia molekul sangat effektif dan effisien didalam pengembangan dan peningkatan produksi suatu lapangan minyak dan gas bumi.
Karakteristik minyak bumi dalam satu lapangan tidak dapat dibedakan dengan sifatsifat umum minyak bumi seperti API gravity, carbon preference index (CPI), flash point, tapi dapat dibedakan dengan pendekatan organik geokimia molekul.

\section{Isoprenoida asiklik}

Isoprenoida alkana asiklik yang paling umum keberadaan dalam bumi ialah pristana (I*), kemungkinan berasal dari phitil, rantai samping dari *klorophil (Didyk dkk, 1978) atau dari archaebacteria (Chappe dkk, 1982; Illch, 1983; Goossens dkk, 1984; Rowland, 1990). Pristana juga dilaporkan terdapat dalam zooplakton dan alga (Blumer, 1965) dimana phytana (II) mungkin juga turunan dari bakteri (Rissati dkk, 1984).

\section{Pristana/Phytana}

Pristana/Phytana $(\mathrm{Pr} / \mathrm{Ph})$ digunakan sebagai indikator untuk mengetahui tingkat kandungan oksigen dalam sampel pada suatu lingkungan pengendapan (Powell dan Mc Kirdy, 1973; Didyk dkk, 1978). Konsep ini didasarkan dari turunan phitol yaitu suatu rantai samping klorofil. Dalam kondisi

\footnotetext{
* Semua angka Romawi di dalam bacaan merujuk pada Gambar 1.
} 
lingkungan oksidatif phitol dirubah menjadi asam phitanoat, dimana berikutnya phitanoat mengalami dekarboksilasi membentuk pristana. Dalam kondisi lingkungan reduktif phitol diubah menjadi dihidrophitol, selanjutnya mengalami reduksi menjadi fitana (II) (Didyk dkk, 1978). (Volkman dan Maxwell 1986) menyarankan bahwa rasio $\mathrm{Pr} / \mathrm{Ph}$ tidak tepat untuk mengindikasikan tingkat oksigenitas dari sampel yang belum matang immature. Sedangkan (Peters dan Moldowan 1993) menyarankan kisaran antara 0,8 sampai dengan 2,5 dianggap meragukan dan oleh karenanya harus ditunjang dengan bukti lain. Dalam penelitian terbaru (Murray dkk, 1994) menggunakan $\mathrm{Pr} / \mathrm{Ph}$ bersamaan dengan data biomarker lain untuk mengklasifikasikan sampel minyak dari kawasan Asia Tenggara kedalam enam lingkungan pengendapan yang berbeda. Secara garis besar dapat di terangkan sebagai berikut: tingginya kandungan $\mathrm{Pr} / \mathrm{Ph}>3$ mengindikasikan lingkungan fluvio - delta dan kelimpahan tumbuhan tinggi tetap, rasio $\mathrm{Pr} / \mathrm{Ph}$ (1,5-3) lingkungan danau dan transisi air tawar : dimana lingkungan danau mengandung 4-metil sterana $>$ dari pada $\mathrm{C}_{30}$ sterana. Delta marin dicirikan dengan $\mathrm{Pr} / \mathrm{Ph}$ rendah (1-3) dan kelimpahan biomarker tumbuhan tinggi dengan kandungan $\mathrm{C}_{29}$ sterana melimpah dan $\mathrm{C}_{30}$ sterana terdeteksi pasangannya.

\section{Sterana}

Sterana (III) merupakan biomarker yang terdapat dalam sedimen. Prekursor sterana ialah sterol yang tersebar luas dalam tumbuhan tinggi dan alga (Mackenzie dkk, 1982 a; Moldowan, 1984; Volkman 1986;
Volkman dkk, 1994). Senyawaan dengan jumlah atom karbon 27 sampai karbon 29 umumnya melimpah dalam steroid hidrokarbon. Huang dan Meinshein (1976) melaporkan senyawa sterol terdapat dalam plankton marin, bahwa senyawa sterolnya terutama mengandung $\mathrm{C}_{27}$ dan $\mathrm{C}_{28}$ dimana $\mathrm{C}_{27}$ relatif lebih besar dari $\mathrm{C}_{28}$. Oleh karena itu $\mathrm{C}_{27}$ sterana dipakai sebagai indikasi material organik batuan sumber yang berasal dari marin. Di dalam hewan dan tumbuhan tinggi terdapat sterol terutama mengandung $\mathrm{C}_{27}$ dan $\mathrm{C}_{29}$ dan kelimpahan $\mathrm{C}_{29}$ relatif lebih besar dari pada $\mathrm{C}_{27}$. Oleh karena itu $\mathrm{C}_{29}$ sterana dipergunakan sebagai indikator material organik batuan sumber berasal dari tumbuhan tinggi atau berasal dari daratan (Huang dan Meinschein, 1979). $\mathrm{C}_{29}$ sterana dalam famili/jenis alga tertentu diketemukan Volkman (1986), tingginya kelimpahan $\mathrm{C}_{29}$ sterana dalam sampel minyak kemungkinan juga tidak mengindikasikan kontribusi tumbuhan tinggi terhadap sampel minyak (Grantham, 1986).

Salah satu isotop stabil yang sering digunakan dalam penelitian dan penggunaan dalam dunia perminyakan ialah ${ }^{13} \mathrm{C}$. Nilai $\delta{ }^{13}$ Csat dan $\delta{ }^{13}$ Caro untuk minyak bumi sekitar $-18 \%$ sampai $32 \%$. Canonial value diperoleh dari perhitungan antara $\delta{ }^{13}$ Csat dan $\delta{ }^{13}$ Caro.

Tujuan penelitian mengidentifikasi beberapa biomarker sebagai parameter korelasi batuan sumber dan lingkungan pengendapan batuan sumber untuk tujuh ( 7 ) sampel minyak bumi lapangan - Tarakan Kalimantan Timur.

Tabef 1. Beberapa sampel senyawaan biomarker dengan sumber biolngi

\begin{tabular}{|c|c|c|c|}
\hline Bomatker & Sumber biologi & Liagkingan & Risilar \\
\hline 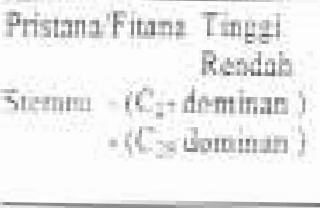 & $\begin{array}{l}\text { Tumbuhan tinge } \\
\text { Ags } \\
\text { Algs } \\
\text { Algs zuas iumbohan } \\
\text { tinggi }\end{array}$ & $\begin{array}{l}\text { Oksidanif } \\
\text { tteciuknif } \\
\text { Maris } \\
\text { Mariil Diratun }\end{array}$ & $\begin{array}{l}1 \\
2 \\
3 \\
4,5\end{array}$ \\
\hline
\end{tabular}




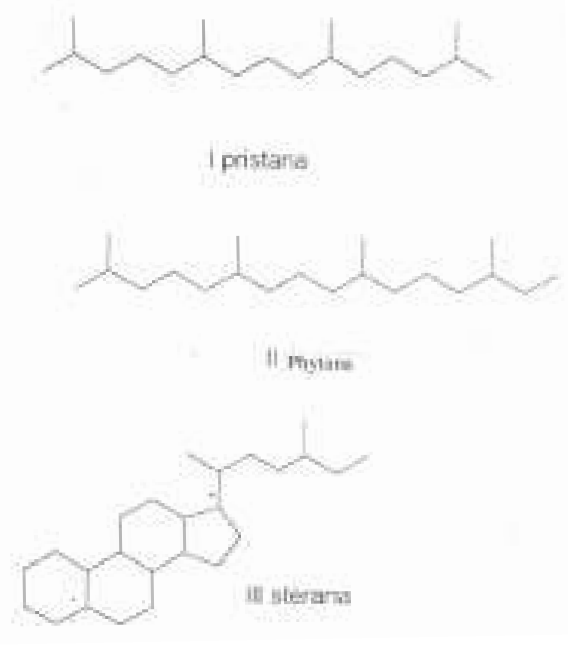

Gambar 1. Struktur biomarker

\section{Bahan dan Metode}

\subsection{Bahan yang digunakan}

Semua pelarut yang dipergunakan seperti n-heksana ( $\mathrm{td}=69^{\circ} \mathrm{C}$ Merck), dichlorometana $\mathrm{DCM}\left(\mathrm{td}=40^{\circ} \mathrm{C}\right.$, Merck), metanol (td = $64,7^{\circ} \mathrm{C}$, Merck ), aseton ( tu $=56,5^{\circ} \mathrm{C}$, Merck ) semua berkualitas pro analisis p.a.a

Silika gel $60 \mathrm{~F}-254$ (Merck) ukuran $0,063-0,200 \mathrm{~mm}(70-230$ Mesh ASTM $)$ digunakan untuk kromatografi kolom diaktifkan pada temperatur $120^{\circ} \mathrm{C}$ selama semalam sebelum dipergunakan.

Moleculer sieves silicalite berupa pelet (Union Carbide) digerus sehingga berupa tepung, dipanaskan pada temperatur $500^{\circ} \mathrm{C}$ selama semalam, kemudian dipindahkan ke dalam oven dengan temperatur $120^{\circ} \mathrm{C}$. Moleculer sieves digunakan untuk kromatografi molekular.

\subsection{Pendekatan analisis geokimia}

Sebelum dilakukan analisis dengan GC, GC-MS, IR-MS perlu dilakukan persiapan pada sampel minyak. Pertama-tama minyak harus bebas air, kedua meningkatkan kandungan senyawaan yang akan dianalisis.

\subsection{Kromatografi gas - Spektrometri massa} (GC-MS)

Analisis GC-MS untuk tujuh sampel saturat bercabang dan saturat siklik yang mewakili dengan Hewlett Packard 5890 yang dilengkapi dengan kolom ultra fused Silika (HP-1), ukuran kapiler $30 \mathrm{~m}$ x 1,25 mm (i.d.) berdasarkan metode West (1989) GC tersebut dihubungkan dengan Hewlett Packard 5970 MSD - komputer (RTE/A) sistem data pengaturan suhu tergantung dari senyawaan yang dianalisis, pada percobaan ini $\mathrm{m} / \mathrm{z} 217$ untuk golongan sterana.

\subsection{Persiapan sampel}

Sampel minyak bumi dari lapangan mengandung air untuk itu dilakukan pemisahan dengan pipet, dimasukkan dalam vial (botol kecil) pengerjaan ini dilakukan dua kali, kemudian dikeringkan dengan $\mathrm{Na}_{2} \mathrm{SO}_{4}$ kemudian dipisahkan lagi. Diberi label disimpan dalam lemari pendingin.

\subsection{Fraksinasi minyak bumi}

Fraksi saturat, aromat dan polar didapat dengan cara fraksinasi minyak bumi, dengan kolom yang padat dari silika $60 \mathrm{~F}-254$ (E. Merck), diperlukan empat gram silika untuk setiap percobaan. Tuangkan n-heksana pada beaker yang berisi silika dan aduk sampai rata, tuang ke kolom sambil digetarkan, sehingga didapat kolom yang padat. Lebih kurang $75 \mathrm{mg}$ minyak ditimbang dalam vial, dengan perlahan-lahan minyak diteteskan pada kolom yang telah disiapkan. Berturutturut dituangkan $36 \mathrm{~mL}$ n-heksana, $32 \mathrm{~mL} 10$ $\%$ DCM dalam n-heksana terakhir $15 \mathrm{~mL}$ DCM dan $15 \mathrm{~mL}$ metanol sehingga didapat fraksi saturat, aromat dan polar.

Masing - masing fraksi dihilangkan pelarutnya dengan memanaskan dalam bak pasir kuarsa pada pemanas listrik, dipindahkan ke vial, dikeringkan dengan pemanas listrik sehingga diperoleh berat yang tetap, kemudian ditimbang.

\subsection{Isolasi alkana bercabang dan siklik}

Bubuk silicalite kering $(0,5 \mathrm{~g})$ dimasukkan dan dipadatkan dalam sebuah pipet Pasteur yang di dasarnya berisi katun bersih, kolom dibilas dengan n-heksana sebelum dipakai. Fraksi saturat dengan berat antara $2-15 \mathrm{mg}$ dalam n-heksana dituangkan dalam kolom dan dibiarkan 
selama 5 menit, kemudian dielusi dengan nheksana sebanyak empat kali volume silicalite, eluen ditampung dalam vial, pelarutnya diuapkan pelan-pelan, residu silicalite berisi n-alkana, sedangkan nheksana yang ditampung mengandung alkana bercabang dan siklik. Alkana bercabang dan siklik disimpan untuk analisis selanjutnya.

\subsection{Metoda analisis dan instrumentasi}

Tujuh sampel yang mewakili diperlakukan sehingga didapat fraksi alkana bercabang dan alkana siklik. Dalam fraksinasi ini digunakan metoda molekular sieving dengan silicalite sebagai fasa padat. GC-MS digunakan untuk analisis biomarker dari fraksi alkana bercabang dan siklik.

\section{Kromatografi gas (GS)}

Analisis GC dilakukan untuk tujuh sampel Kromatografi gas - spektrometri massa (GC-MS). Analisis GC-MS untuk tujuh sampel saturat bercabang dan saturat siklik yang mewakili dilakukan dengan Hewlett Packard 5890 yang dilengkapi dengan kolom ultra fused Silika (HP-1), ukuran kapiler $30 \mathrm{~m}$ x $1,25 \mathrm{~mm}$ (i.d.) berdasarkan metode West (1989) GC tersebut dihubungkan dengan Hewlett Packard 5970 MSD - komputer (RTE/A) sistem data pengaturan suhu tergantung dari senyawaan yang dianalisis $\mathrm{m} / \mathrm{z}$.

\section{Kromatogram massa}

\section{Sterana}

GC - MS digunakan untuk analisis sterana, monitoring pada $\mathrm{m} / \mathrm{z}$ 217. Kromatografi massa $\mathrm{m} / \mathrm{z} 217$ digunakan untuk mengidentifikasikan sterana diantara kompleks $\mathrm{C}_{27}-\mathrm{C}_{30}$ di daerah waktu retensinya. Identifikasi puncak dalam kromatogram massa dibandingkan dengan data waktu retensinya yang telah dipublikasikan.

\section{Hasil dan Pembahasan}

Pembahasan hasil analisis GC yaitu rasio pristana terhadap fitana. Hasil analisis GCMS yaitu kandungan 20R untuk $\mathrm{C}_{27}, \mathrm{C}_{28}$ dan $\mathrm{C}_{29}$ dan IR-MS $\left(\mathrm{Cv}, \delta^{13} \mathrm{C}_{\text {sat }}\right.$ serta $\left.\delta^{! 3} \mathrm{C}_{\text {aro }}\right)$

\section{$\mathbf{P r} / \mathbf{P h}$}

Tabel 2. Data biomarker alkana bercabang dari sampel minyak

\begin{tabular}{lll}
\hline \multicolumn{2}{c}{ Sampel } \\
No & Sumur & $\mathrm{Pr} / \mathrm{Ph}$ \\
\hline 1. & $\mathrm{A}-1$ & 2,88 \\
2. & $\mathrm{B}-2$ & 2,32 \\
3. & $\mathrm{C}-1$ & 4,24 \\
4. & $\mathrm{D}-1$ & 4,05 \\
5. & $\mathrm{E}-2$ & 6,89 \\
6. & $\mathrm{E}-3$ & 4,43 \\
7. & $\mathrm{F}-1$ & 6,91 \\
\hline
\end{tabular}

Dari hasil analisis GC terhadap ke 7 sampel minyak bumi lapangan Tarakan, diperoleh data $\mathrm{Pr} / \mathrm{Ph}$ untuk masing - masing sumur seperti ditunjukkan Tabel 2. Dari data tersebut ternyata kisaran $\mathrm{Pr} / \mathrm{Ph}$ untuk sampel tersebut antara 2,32 sampai dengan 6,91 dimana nilai yang terendah terekam pada sumur B2 dan tertinggi untuk sumur F1. Lebarnya kisaran tersebut menunjukkan bervariasinya lingkungan pengendapan. Sebanyak enam minyak bumi yaitu A1 C1, D1, E2, E3 dan F1 dicirikan dengan $\mathrm{Pr} / \mathrm{Ph}>4$ dan sekitar 3 , satu yaitu B2 dengan nilai 2,32. Fakta ini mengindikasikan adanya dua kelompok material organik batuan sumber. Menurut Didyk dkk. (1978), rasio tersebut menunjukkan perbedaan tingkat oksigen dalam suatu lingkungan pengendapan batuan sumber. Sampel dengan nilai $\mathrm{Pr} / \mathrm{Ph}>3$ umumnya mengindikasikan asal dari suatu lingkungan pengendapan oksidatif sedangkan lingkungan pengendapan reduktif bila nilai $\mathrm{Pr} / \mathrm{Ph}<3$.

Kelimpahan pristana atas fitana $(\mathrm{Pr} / \mathrm{Ph}>3)$ mengindikasikan asal material organik batuan sumber dari daratan jenis fluvio- $\delta$ (Muray dkk,1994), sedangkan untuk sampel dengan nilai $\mathrm{Pr} / \mathrm{Ph}$ antara 1,5-3 mengindikasikan material organik batuan sumber berasal dari lingkungan marin. Dari hasil penelitian didapat nilai rasio sterana 20R $\mathrm{C}_{29} / \mathrm{C}_{27}$ untuk ketujuh sampel minyak bumi 
lapangan Tarakan bersumber dari material organik berasal dari daratan seperti ditunjukkan pada tabel 3, dimana rasio $\mathrm{C}_{29} / \mathrm{C}_{27}$ lebih besar dari satu.hal ini mengindikasikan ketujuh batuan sumber organik berasal dari daratan.

Dengan menggunakan IR-MS diperoleh data isotop ${ }^{13}$ Carbon seperti ditunjukkan Tabel $4, \delta{ }^{13}$ Carbon masing-masing fraksi saturat dan aromat untuk tujuh (7) sampel minyak bumi lapangan Tarakan didapat kisaran nilai $\delta{ }^{13}$ Csat antara $-30 \%$ sampai dengan $-28,59 \%$ dimana minyak F1 terendah dan E3 tertinggi, sedangkan $\delta{ }^{13}$ Carbon berkisar antara $-27,88 \%$ sampai dengan 27,22 \%o, dari grafik antara $\mathrm{Cv}$ terhadap terhadap $\mathrm{Pr} / \mathrm{Ph}$ dimana $\mathrm{Cv}$ dan $\mathrm{Pr} / \mathrm{Ph}$ masingmasing sebagai $\mathrm{y}$ dan $\mathrm{x}$ material organik batuan sumber minyak bumi A1, C1, E2 dan F1 terletak di daerah terrestrial (daratan) karena Cv masing-masing $>0,47$ (Sofer,1984) dan $\mathrm{Pr} / \mathrm{Ph}>3$, sisanya berada disekitar batas terrestrial dan marin. Fakta ini mengindikasikan material organik batuan sumber untuk A1, C1, E2 dan F1 berasal dari daratan, sisanya berasal dari campuran daratan dan marin.

Tabel 3. Data biomarker $20 \mathrm{R}$ sterana $\mathrm{C}_{27}, \mathrm{C}_{28}, \mathrm{C}_{29}$ minyak bumi lapangan Tarakan

\begin{tabular}{|c|c|c|c|c|c|}
\hline \multirow[b]{2}{*}{ No. } & \multicolumn{4}{|c|}{ \% komposisi } & \multirow[b]{2}{*}{$\mathrm{C}_{29} / \mathrm{C}_{2}$} \\
\hline & Sumur & $20 \mathrm{RC}_{27}$ & $20 \mathrm{RC}_{28}$ & $20 \mathrm{RC}_{29}$ & \\
\hline 1. & $A-1$ & 0,17 & 0,23 & 0,60 & 3,5 \\
\hline 2. & $B-2$ & 0,23 & 0,21 & 0,56 & 2,4 \\
\hline 3. & $C-1$ & 0,15 & 0,25 & 0,59 & 3,9 \\
\hline 4. & $D-1$ & 0,10 & 0,17 & 0,73 & 7,3 \\
\hline 5. & $E-2$ & 0,21 & 0,26 & 0,60 & 2,9 . \\
\hline 6 & $E-3$ & 0,17 & 0,19 & 0,64 & 3,8 \\
\hline 7. & F - 1 & 0,20 & 0,29 & 0,51 & 2,6 \\
\hline
\end{tabular}

Tabel 4. Data biomarker isotop ${ }^{13} \mathrm{C}$ dan $\mathrm{C}_{\mathrm{v}}$ minyak bumi lapangan Tarakan

\begin{tabular}{crrrr}
\hline \multicolumn{5}{c}{${ }^{\delta}$ Isotop ${ }^{13}$ Carbon } \\
No. & Sumur & SAT & ARO & $C_{v}$ \\
\hline 1. & A -1 & $-29,06$ & $-27,56$ & 0,69 \\
2. & B -2 & $-28,87$ & $-27,50$ & 0,34 \\
3. & C -1 & $-29,28$ & $-27,74$ & 0,85 \\
4. & D -1 & $-28,86$ & $-27,22$ & 0,18 \\
5. & E -2 & $-29,91$ & $-27,62$ & 2,71 \\
6 & E -3 & $-28,59$ & $-27,88$ & $-1,21$ \\
7. & F - 1 & $-30,00$ & $-27,77$ & 2,60 \\
\hline
\end{tabular}




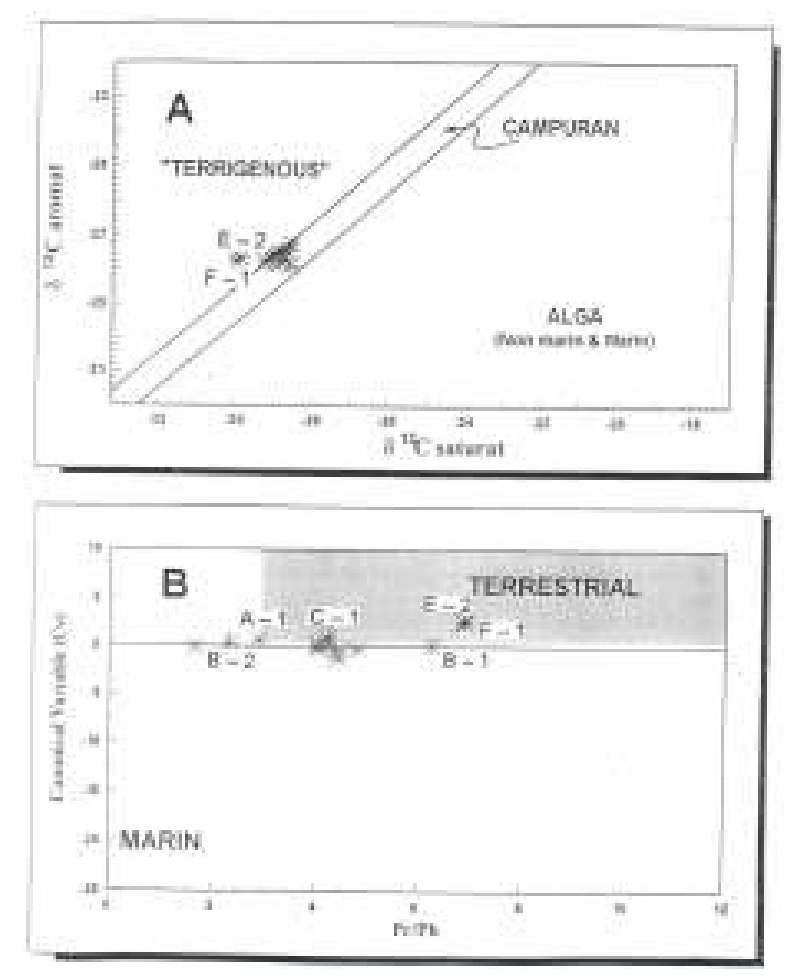

Gambar 2. A. Plot antara $\delta 13 \mathrm{C}$ saturat terhadap aromat untuk lapangan Tarakan, minyak bumi E-2 dan F-1 berada di daerah senyawaan organic batuan sumber berasal dari daratan. B Plot antara $\mathrm{Pr} / \mathrm{Ph}$ terhadap $\mathrm{Cv}$ untuk lapangan Tarakan, minyak E-2, F-1, C-1, A-1 dan B-2 berada di daerah senyawaan organic batuan sumber berasal dari daratan.

\section{Kesimpulan dan Saran}

Berdasarkan penelitian yang telah dilakukan dapat diambil beberapa kesimpulan. 1) Material organik batuan sumber berasal dari lingkungan daratan, campuran marin dan daratan berdasarkan tiga parameter. Adanya $\mathrm{C}_{29}>\mathrm{C}_{27}$ sterana, Canonial value $(\mathrm{Cv})$, grafik antara $(\mathrm{Pr} / \mathrm{Ph})$ sebagai absis dan $\mathrm{Cv}$ sebagai ordinat ketiga data tersebut merupakan bukti material organik batuan sumber yang berasal dari daratan, tipe minyak termasuk delta. 2) Kondisi lingkungan pengendapan minyak bumi lapangan Tarakan bervariasi dicirikan dengan lebarnya kisaran $\mathrm{Pr} / \mathrm{Ph}(1,66-6,91)$ sebagian besar bersifat oksidatif, satu bersifat reduktif yaitu B2.

\section{Saran}

Dua parameter dari karakteristik fluida di dalam reservoar lapangan Tarakan telah diteliti, masih ada beberapa yang belum diteliti, untuk itu perlu dilakukan penelitian lanjutan sehingga diperoleh data yang lebih lengkap, sehingga pemahaman reservoar lebih mendalam.

\section{Daftar Pustaka}

Blumer M. and Snyder W.D. (1965) Isoprenoid hydrocarbons in recent sediments. Presence of pristane and probable absence of phytane. Science 150, 1588-1589.

Chappe B., Albrecht P. and Michaelis W. (1982) Polar lipids of archaebacteria in sediments and petroleum. Science 217, 65-66.

Didyk B. M., Simoneit B. R. T., Brassell S. C. and Eglinton G. (1978) Organic geochemical indicators of palaeoenvironment conditions of sedimentation. Nature 272, 216-221.

Goosens H., de Leeuw J.W., Schenck P. A. and Brassell S. C. (1984) Tocopherols as likely precursors of pristane in ancient sediments and crude oil. Nature 312, 440-442.

Illich H. A. (1983) Pristane, phytane and lower molecular weight isoprenoid distributions in oils. Am. Assoc. Pet. Geol. Bull. 67, 385-393.

Murray A.P., Summons R. E., Boreham C. J. and Dowling L. M. (1994b) Biomarker and nalkanes isotope profiles for tertiary oils: An organofacies approach. In Advances in Organic Geochemistry 1993 (Edited by

Peters K. E., Moldowan J. M. (1993) The Biomarkers Guide, Interpreting Molecular Fossils in Petroleum and Ancient Sediments, 363 p, Prentice-Hall, Englewood Cliffs, N. J.

Powell T. G. and McKirdy D. M. (1973) Relationship between ratio of pristane to phytane, crude oil composition and geological environment in Australia. Nature 243, 37-39. 
Rissati J. B., Rowland S. J., Yan D. A. and Maxwell J. R. (1984) Stereochemical studies of acyclic isoprenoids - XII. Lipids of methanogenic bacteria and possible contributors to sediments. Org. Geochem. 6, 93-104.

Rowland S. J. (1990) Production of acyclic isoprenoid hydrocarbons by laboratory maturation of metanogenic bacteria. Org. Geochem. 9, 153-161.

Rullkotter J. and Marzi R. (1989) New aspects of the application of sterana isomerisation and steroid aromatisation of petroleum exploration and the reconstrunction of geothermal histories of sedimentary basins. Preprints 34,126-134.

Seifert W. K. and Moldowan J. M. (1986) Use of biological markers in petroleum exploration. In Biological Markers in the Sedimentary Record (Edited by Johns R. B.), Methods in Geochemistry and Geophysics 24,pp. 261-290. Elsevier, Amsterdam.

Sosrowidjojo I.B., (1995) Plant Biomarker and Their Application for Assessing The Maturity of Petroleum, Thesis Doctor of Philosophy, Curtin University of Technology, Australia

Sosrowidjojo I.B.,Murray A.P., Alexander R., Kagi R.I. and Summons R.E.(1996) Bicadinanes and related compounds as muturity indicator for oils and sediments. Org. Geochem. 24, 43-55.

Ten Haven, H.L. and Schifelbein C.F. (1995). The petroleum system of Indonesia. In Proc. IPA., $24^{\text {th }}$ Ann. Conv., pp. 443-459, Indonesian Petroleum Association, Jakarta.

Tissot B. P. and Welte D. H. (1984) Petroleum Formation and Occurance, 699p, SpringerVerlag, Berlin.

West N., Alexander R. and kagi R.I.(1989) The use silicalite for rapid isolation of branched and cyclic fractions of petroleum. Org. Geochem. 15, 499-502.

Volkman J. K. (1986) A review of sterol markers for marine and terrigenous organic matter. Org. Geochem. 9, 84-99. 